\title{
Images of the Good Ruler in Sasanian Iran: An Emic View
}

Gustav Adolf Lehmann with gratitude

\section{Introduction}

\begin{abstract}
At this juncture it came about that Cabades became seriously ill, and he called to him one of the Persians who were in closest intimacy with him, Mebodes by name, and conversed with him concerning Chosroes and the kingdom, and said he feared the Persians would make a serious attempt to disregard some of the things which had been decided upon by him. But Mebodes asked him to leave the declaration of his purpose in writing, and bade him be confident that the Persians would never dare to disregard it. So Cabades set it down plainly that Chosroes should become king over the Persians. The document was written by Mebodes himself, and Cabades immediately passed from among men. And when everything had been performed as prescribed by law in the burial of the king, then Caoses, confident by reason of the law, tried to lay claim to the office, but Mebodes stood in his way, asserting that no one ought to assume the royal power by his own initiative but by vote of the Persian notables. So Caoses committed the decision in the matter to the magistrates, supposing that there would be no opposition to him from there. But when all the Persian notables had been gathered together for this purpose and were in session, Mebodes read the document and stated the purpose of Cabades regarding Chosroes, and all, calling to mind the virtue of Cabades, straightway declared Chosroes King of the Persians. (transl. H.B. Dewing)
\end{abstract}

As can be inferred from the quotation from Procopius' Persian Wars (1.21.17-22), the Sasanian king's eldest son Kāūs (Caoses) claimed the succession after the death of Kawād I (Cabades). The aristocrat Māhbōd (Mebodes), however, pointed out on this occasion that a legitimate ruler could only be confirmed by a vote of the Persian

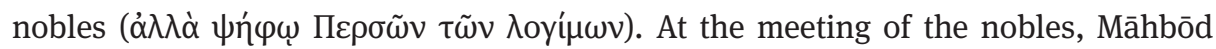
read aloud a letter that Kawād had written shortly before his death, in which he expressed the wish that his third son, Khosrō (Chosroes), should ascend the throne. According to Procopius, the assembly, to which even the highest clerics must have belonged, then gave its consent to Kawād's wish. In other words, although primogeniture was the usual criterion of succession in Sasanian Iran, designation by the predecessor could also be used as a guideline. Both regulations were quite risky, and their outcome not at all certain, as is witnessed by the numerous disputed successions in the Sasanian empire, but both were formally bound to noble acclamation.

For commenting on parts of this contribution, I wholeheartedly thank, apart from the participants of the Frankfurt conference, Carole and Robert Hillenbrand, Jaakko Hämeen-Anttila (all from Edinburgh) and Henning Börm (Konstanz). 
Procopius's report of the succession of September 531 CE mentions a further criterion of the royal succession, already observed in many monarchical systems including Achaemenid Iran, namely that a hereditary prince must also be free from physical infirmity. Thus, Kawād's second son Zām could not become king, since it

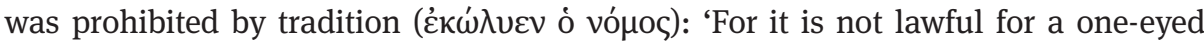
man or one to have any other deformity to become king over the Persians' (Procop., pers. 1.11.4). This threw the gates wide open for the intentional mutilation of competitors and princely rebels. Thus, Khosrō I, who had just benefited from the regulation of his father and the acclamation by the great men of the empire, had his rebellious eldest son Anōšagzād's (Anasozados') eyelashes scorched with red-hot iron depriving him of his claim to the throne (Procop., goth. 8.10.8-22).

Royal successions, as in all similarly structured monarchical systems, were always potential times of crisis in the Sasanian Empire due to the large number of eligible princes and the impossibility of double reign. It should not surprise us that Zoroastrian writings, such as the famous 'Letter of Tansar' from the sixth century, and early Islamic historiography, such as aț-Tabarī, particularly emphasise the decisive voting role of the mowbedan mowbed, the supreme cleric of the empire, in the process of the appointment of a new ruler. Rather, in light of the original context of the writings and the intentions of their authors, it should make us sceptical about the statements' accuracy.

If foreign and Iranian traditions agree on the ways of the appointment of a new ruler in the Sasanid kingdom, ${ }^{1}$ this does not apply to their definitions of a good or even ideal ruler. Philip Huyse, for example, has shown in a fundamental contribution to the debate about Sasanian royal titulature ${ }^{2}$ that Eastern Roman tradition used alleged Sasanian titles to express the inferiority and sometimes also the arrogance and hubris of the Eastern adversary and partner. This is why it seems appropriate for me not to present the good or even ideal Iranian ruler from a foreign point of view, not even from the perspective of a neutral observer, but rather 'with the eyes of an insider' of Sasanian courtly culture, i.e., in the form of a description that is best understood from the perspective of a participant of this culture.

But before I try to present my ideas on this kind of emic view of ideal Sasanian kingship, let me first discuss some problems with sources connected to that topic.

1 For successions to the throne in Sasanian Iran, cf. particularly H. Börm, Das Königtum der Sasaniden - Strukturen und Probleme. Bemerkungen aus althistorischer Sicht, in: Klio. Beiträge zur alten Geschichte 90, 2008, 423-443 (for 531 CE: 433-435) and P. Huyse, Die königliche Erbfolge bei den Sasaniden, in: P. Gignoux/C. Jullien/F. Jullien (eds.), Trésors d'Orient. Mélanges offerts à Rika Gyselen (Studia Iranica. Cahiers 42), Paris 2009, 145-157.

2 P. Huyse, Die sasanidische Königstitulatur. Eine Gegenüberstellung der Quellen, in: J. Wiesehöfer/P. Huyse (eds.), Ērān ud Anērān. Studien zu den Beziehungen zwischen dem Sasanidenreich und der Mittelmeerwelt (Oriens et Occidens 13), Stuttgart 2006, 181-201. 


\section{Source Problems}

First, scholars of Islamic studies have, on the one hand, emphasised time and again that the historical Iranian tradition - or rather the historical Iranian traditions - have been, among others, considered important predecessors of Early Islamic historiography. On the other hand, only few of them have aimed at meticulously investigating and characterising the early Arab-Islamic authors' handling of these traditions. This is in contrast to those many works that have focused on the development and the manner of presentation of the pre-Islamic history of Iran in the universal histories of the Abbasid period.

Conversely and for quite some time, Iranists and ancient historians have dealt intensively with the peculiarities of these precursor traditions that underwent long periods of orally handing down information - but, whose afterlife and impact were often only treated superficially. These pre-Islamic Iranian traditions, long subject to the rules of oral transmission and put into writing usually only in late Sasanian or even post-Sasanian times, were probably less uniform than scholars thought when suggesting a multiform, normative and semi-official "Book of Lords" (Khw adāynāmag). The ways in which these traditions became part of Early Islamic historiography were probably much more varied and intertwined than was long and commonly assumed, even by me. There were centuries between the creation of the first $K h^{w} a d \bar{a} y$ nāmag and the edition of Firdausì's Shāhnāmeh (c. 1000), works that are normally associated with each other without much hesitation - the $K h^{w}$ adāy-nāmag is sometimes even simply reconstructed from the Shāhnāmeh. In reality, there was great latitude for various literary plans and imaginations of authors, for diverse interests, preferences and legitimisation efforts of princely principals or consumers, and for the compliance with or the abandonment of genre-specific requirements, rules and expectations.

Much other 'historical' material, in addition to the $K h^{w} a d \bar{a} y$-nāmag-tradition, circulated in Iran in late Sasanian and early Islamic times, material that the Fihrist noted by its titles. And Ibn al-Muqaffa', Ḥamza Ișfahānī, at-Ṭabarī, Dīnawarī, Ibn Qutayba and other writers probably had, within their framework of a sacred and/or universal history, enormous leeway for their own specific modes of composition, emphasis, rating and processing of that Persian historical material and information. ${ }^{3}$ This is

3 For the Khwadāy-nāmag and its influence on Arabic and Persian historiography, see J. Hämeen-Anttila (Khwadāynāmag. The Middle Persian Book of Kings (Studies in Persian Cultural History 14), Leiden 2018. Cf. already his: Ibn al-Muqaffa' and the Middle Persian Book of Kings. Contacts and interaction, in: J. Hämeen-Anttila/P. Koskikallio/I. Lindstedt (eds.), Proceedings of the 27th Congress of the Union Européenne des Arabisants et Islamisants, Helsinki 2014 (Orientalia Lovaniensia Analecta 254), Leuven 2017, 171-184. For pre-Islamic historical writing and its transmission, see also 'The History of the Kings of the Persians' in Three Arabic Chronicles. The Transmission of the Iranian Past from Late Antiquity to Early Islam. Translated with Introduction and Notes by R.G. Hoyland (Translated Texts for Historians 69), Liverpool 2018. While agreeing on the fact that the $K h^{w} a d \bar{a} y-n \bar{a} m a g$ was 
even more true in view of the fact that the link between Ibn al-Muqaffa' and all subsequent historians that Theodor Nöldeke proposed is assumed, but not really proven. ${ }^{4}$ In other words, we have to imagine the process of the emergence of Persian and Arabic historical tradition, such as that of the "Book of Kings" or the Annals of aț-Ṭabarī, to have been a lot more complicated than commonly assumed. ${ }^{5}$

Second, our evidence points to a growing literate reading society in Iran beginning in the sixth-seventh century CE, an elitist society that increasingly sought to put information into writing. As for historical traditions, this development may, inter alia, have been due to the Iranians' reaction to the impressive Byzantine or SyriacChristian historical tradition. Previously, script had been more or less a matter of professional scribes, and Iran had only been exposed to a very limited process of literacy. However, it would be wrong to measure an oral society by the standards of a literate one. Historical traditions in an oral society are dynamic and often adapt to the needs of influential contemporary groups: the official story of a new dynasty usually moves along the policy patterns and value systems of its predecessors, but the knowledge of concrete names and specific actions of these precursors disappears over time when people are confronted with new historical or literary contexts. A deliberate damnatio memoriae of the predecessors is not excluded either, as is proven by the displacement of the Arsacids from the so-called Iranian National History in late Sasanian times. And the introduction of a script system is not identical with the disappearance of oral traditions, nor does the existence of a centre-based written tradition imply the abandonment of local or regional traditions.

\section{Royal Authority and Legitimation of Rule}

Let us now come back to our specific topic: the image of the ideal ruler. From what do the Sasanian rulers, according to the sources of the Sasanid and early Islamic period, derive their authority? What legitimates their rule? The following ritualised dialogue between Narseh (293-302) - son of Šābuhr and grandson of Ardašīr and opponent of Diocletian and his Caesar Galerius - and the magnates of the empire is found in the inscription of the Sasanian šāhān šāh from Pāikūlì in Iraqi Kurdistan (NPi 73, 86, 89f., transl. P.O. Skjærvø):

probably just a rather dry chronicle with a list of Persian kings, Hämeen-Anttila and Hoyland have divergent views of the origins of the narrative material about pre-Islamic Persia extant in the medieval sources and of the history of early Arabic and Persian historiography.

4 T. Greenwood, Sasanian Echoes and Apocalyptic Expectations: A Re-Evaluation of the Armenian History attributed to Sebeos, in: Mus 115.3-4, 2002, 323-397, 329.

5 Apart from the literature mentioned in fn. 3, cf. also M.R.J. Bonner, Three Neglected Sources of Sasanian History in the Reign of Khusraw Anushirvan (Studia Iranica. Cahier 46), Leuven 2011. 
If the landholders [know that in Ërānšahr there is someone who?] would be more righteous and better and more pious with respect to the gods than Ourself or [who would be more able] than Ourself [to keep] Ërānšahr in peace [and confident and to govern the affairs of the Persians and ... and] to answer... and enemies, let him say so now, so that [he may be lord of?] the Realm and (its various) districts [who] is able to keep and govern the realm.

$\cdots$

[And from the Hargbed] and the landholders [šahrdārān] and the princes [wāspuhragān] [and the grandees [wuzurgān] and the nobles [āzādān] and] the Persians and the Parthians then also a message [and] an answer was brought to Us (saying) thus that: ... "[It is fitting for?] Your Majesty [that You should ascend?] the throne which the gods gave [and (that) You should be [...] and should keep and govern the realm until the time of the Renovation and be happy by Your Own glory and realm.”

...

Then We with the support of and in the name of the gods and Our own [ancestors?] ascent [the throne of?] (Our) father and ancestors.

If one adds other royal self-pronouncements in word and image or information provided by the literature written at court, it appears that in order to be considered an ideal šāhān šāh or kay, a king had to meet five main requirements: ${ }^{6}$ (1) He had to be a member of the Sasanid clan. (2) He must have ascended the throne in the right way. (3) He had to be closely affiliated with the gods. (4) He had to follow the ethical pattern of behaviour set by Ohrmazd and the other gods and thus have been in the possession of the supernatural radiance of the kingly Light, the xwarrah, which conferred success, authority, and also special physical qualities upon the ruler. (5) He had to look after the promotion of the 'good religion' (wehdēn) by supporting the 'priesthood' and the foundation of fires for the salvation of the souls of the dead and the living. Michael Stausberg rightly emphasised that in scenes of investiture in early and late Sasanian relief art the rule of the respective king is 'represented as being willed by God; the exercise of this rule policises and temporalises a "religious" and supratemporal act; the enemies of the king are parallelised with the enemy of the god."7

Some early and late Sasanian reliefs, as well as the hunting bowls of Middle Sasanian times, which replaced the inscriptions and reliefs as media of royal pronouncements, emphasise the physical and moral qualities of the king: an ideal warrior and hunter, an invincible fighter against internal and external threats, and a collaborator in the recovery of the lifeworld created by the gods in good order and threatened or even disintegrated by Ahreman. Philip Huyse has summarised all

6 For the basic requirements and characteristics of Sasanian kingship, see J. Wiesehöfer, King and Kingship in the Sasanian Empire, in: G.B. Lanfranchi/R. Rollinger (eds.), Concepts of Kingship in Antiquity (History of the Ancient Near East, Monographs 11), Padua 2010, 135-152; H. Börm, Königtum (cf. fn. 1) and Kontinuität im Wandel. Begründungsmuster und Handlungsspielräume der iranischen Monarchie in arsakidischer und sasanidischer Zeit; in: S. Rebenich (ed.), Monarchische Herrschaft im Altertum (Schriften des Historischen Kollegs 94), Munich 2017, 545-564.

7 M. Stausberg, Die Religion Zarathushtras, vol. 1, Stuttgart 2002, 213. 
these qualities vividly in the term 'experienced virtuousness' ('praxiserprobte Tugendhaftigkeit'). ${ }^{8}$

The Armenian author Łazar P'arpec $i \mathrm{i}$ demonstrated that lists of these royal virtues crossed the borders of Iran when around 500 CE he ascribes the following description of a good Persian ruler to the sparapet of Armenia, Vahan Mamikonean:

Whoever is lord of the Aryans must contemplate every man with just eyes, like a king, and justly observe and justly listen, as is right for a king. But that king who does not regard his servants with impartial eyes and does not listen to anyone's words with impartial ears, but always conducts himself in an overbearing manner... then heavy is that service and bitter and damaging, something which no-one can endure. (History, tr. R.W. Thomson, p. 137, 11. 17-34)

The good Persian ruler, as Vahan and the tomb inscription of Darius I in Naqsh-i Rustam remind us, was surely 'one who respected Armenian religious traditions and listened in person to the petitions of his Armenian subjects. ${ }^{9}$ A catalogue of such royal virtues is still known in the tenth century, as Eutychius of Alexandria proves when he describes the Sasanian king Wahrām Gōr giving the following advice to the leaders of Persia:

You should only accept as your ruler someone who possesses specific virtues, who is the best expert of religion among you, who is prudent, honest towards the people, who possesses the power of beating, the art of rhetoric, leniency in politics, and the knowledge of stratagems. $\left(\right.$ ann. 233) ${ }^{10}$

Despite all the legendary and early Islamic transformations of the tradition, late antique ideas of a good and successful Iranian king are most prominently displayed in a quotation from the Arab historian and geographer al-Mas'ūdī. According to him, Wuzurgmihr, the famous minister of King Khosrō I, ordered twelve principles for a good king to be written down in gold letters (Murūğ II 206f. de Meynard/de Courteille):

First, fear God in passion, desire, anger, and love, and account for the consequences before God, not before men! Second, say the truth and keep promises, agreements, and contracts! Third, consult the scholars in all things! Fourth, honour the wise, the nobles, the warriors, the army leaders, the clerks, and the court officials according to their ranks! Fifth, take care of the judges and check the accounts of the financial officials, rewarding those who have done their job well, and punishing the others! Sixth, take care of the prisoners with the help of frequent visits, so that you can be sure of the true deceiver and free the innocent! Seventh, take care of the roads, the markets, the prices and the trade! Eighth, chastise the subjects according to the severity of their crimes and apply the legal penalties! Ninth, make sure you have the necessary weapons and everything else available! Tenth, honour your family, your children, your confidants, and examine what is conducive to them! Eleventh, pay close attention to the national borders, so

8 P. Huyse, Erbfolge (cf. fn. 1) 151.

9 Personal communication Tim Greenwood (St. Andrews).

10 I owe this hint to my dear colleague Maria Conterno (Ghent). 
you can make preparations before you fear an attack! Twelfth, check your viziers and servants, and replace the faithless and incapable among them!

Soon after (II 210), the author quotes the following ruling maxims of Anūširwān himself:

The government is dependent on the army, the army on money, money on taxes, taxes on a prosperous agriculture, a prosperous agriculture on justice, justice on the righteousness of officials, and the righteousness of officials on the righteousness of the viziers. But above all is the king's vigilance towards himself and his ability to exercise control over himself so that he can control his feelings and not vice versa. ... The welfare of the people is more helpful than a great army, and the king's righteousness is more useful than times of abundance.

It has often and rightfully been stated that during the early Abbasid caliphate the genre of advice literature 'crystallized around Arabic translations of prose works in Pahlavi ..., ancient Greek ..., and Sanskrit ... concerning ethics and statecraft' and that 'the literature of advice (andarz or pand) - particularly that ascribed to the Sasanians - had the most significant bearing on the subsequent development of Perso-Islamic mirrors for princes. ${ }^{11}$ The early-twelfth-century Nașịhat al-mulūk, a 'treasure-store of Sasanian and Muslim stories and sayings,'12 explains that the 'predecessors (i.e., the Sasanians) (had) lived long lives, (had gone) through many experiences, and learned by experience to distinguish good from bad.'13

Andarz texts are a type of literature containing advice and injunctions for proper behaviour in matters of state, religion or everyday life and they were very popular in late Sasanian Iran, especially in courtly circles. Their popularity is proven in both pre-Islamic and in Islamic times especially by special manuals for the education of princes, surviving only in Arabic and New Persian translations with the Testament of Ardashir and the Letter of Tansar being the most prominent. Numerous andarz compilations were made during the time of Khosrō I, so it is unsurprising that many of those texts were later attributed to the king himself or to his famous counsellor Wuzurgmihr, like in our quotes from al-Mas' $\mathrm{u}$ dì.

11 C.G. Lingwood, Politics, Poetry, and Sufism in Medieval Iran. New Perspectives on Jāmī’s Salāmān va Absāl (Studies in Persian Cultural History 5), Leiden 2014, 35.

12 F.R.C. Bagley, Introduction, in: F.R.C. Bagley (tr.), Ghazāli’s Book of Counsel for Kings (Nașịhat almulūk). Translated from the Persian Text Edited by Jalāl Humā’ī and the Bodleian Arabic Text Edited by H.D. Isaacs (University of Durham Publications), London 1964, IX-LXXIV, XVI.

13 F.R.C. Bagley, Introduction (cf. fn. 13) XXXVI. Only the first of the two parts of the work can confidently be attributed to al-Ghazālī (C. Hillenbrand, A Little-Known Mirror for Princes by al-Ghazālī, in: R. Arnzen/J. Thielmann (eds.), Words, Texts and Concepts Cruising the Mediterranean Sea: Studies on the Sources, Contents and Influences of Islamic Civilization and Arabic Philosophy and Science; Dedicated to Gerhard Endress on His Sixty-Fifth Birthday (Orientalia Lovaniensia Analecta 139), Leuven 2004, 593-602, 597). 


\section{Royal Legitimation in Religious and Mythological Contexts}

It should be understood by now that our definitions of royal qualities have so far been guided by principles that the 'Kings of Kings' had formulated or illustrated themselves, perhaps with the exception of the Mas' $\bar{u}$ di quotation, which was also inspired by post-Sasanid-Islamic ideas. With a quick reminder not to overestimate the influence of clerical elites in the empire, I would like to direct the reader's attention to two particularly striking things: the first is the sacralisation of the Sasanian king's own rule, which is mirrored, for example, in the formula kē čihr az yazdān ('who is the image of the gods' or 'whose origin is from the gods') and which can be found in inscriptions and coin legends until the fifth century as well as in the king's self-designation as a 'Mazda worshipper.' Secondly, there is another form of religious legitimation which refers to the intense concern for the cult sites and the foundation of fires for the souls of the living and deceased members of the royal house and the imperial elites.

But the Sasanian kings localised themselves not only in religious but also in mythical-world-historical contexts when they defined the monarchical ideal of their time or presented themselves as the embodiment of this ideal. Despite the title kay only appearing on Sasanian coin legends in the late fifth century, Rahim Shayegan has additionally postulated that the early Sasanians claimed to be the successors of the mythical Kayanian kings, or, that the Sasanians - by introducing the concept of Ėrān ud Anērān ('Iran and Non-Iran') - created an 'ideological riposte' to Rome's view of its empire as an imperium sine fine. The titulature of the later kings (kay, abzōn ['increase'], xwarrah abzūd ['whose xwarrah is increased' or 'by whom the xwarrah is increased']) is here interpreted as part of an ideological agenda created in reaction to 'Turanian' (sc. Hephthalite and/or Turkic) aggression, or connected with the temporary chance of finally solving the problem of a war on two fronts, respectively. $^{14}$

\section{Iranian Mytho-Historical Traditions}

Finally, let us turn to the mytho-historical Iranian tradition that I mentioned before and that was put into writing for the first time in late Sasanian times. In pre-Sasanian times, the production, upkeep, performance, and transmission of such material was in the hands of singers and minstrels, the so-called gōsān. They performed songs in an epic or poetic form and either travelled from one court or one aristocratic place to

14 M.R. Shayegan, Sasanian Political Ideology, in: D.T. Potts (ed.), The Oxford Handbook of Ancient Iran, Oxford 2013, 805-813. 
another or were members of a noble man's entourage. As with the Homeric epics, the artists had to take into account the tastes, self-images, and interests of an aristocratic audience. Above all, in the pre-Sasanian, especially Kayanid parts of this 'Iranian National History,' neither the priesthood nor the monarchs could outshine the nobility in its role as the real hero of the millenary drama of Iranian history. The charisma of the king and his house was not denied, even if he was an unfair or incompetent monarch. However, he was not a god-like figure, free of all criticism and with an unlimited sovereignty, but often a rather sad figure of a more than dubious humanness. It was the prominent representatives of the high nobility in whose hands the destiny of the land lay, and it was this nobility that found the gōsān poetry's real sympathy. There is much to be said for the fact that in the course of time the glorification of certain noble houses became an important feature of the singers' poetry and took on a more concrete, historical shape until the time of the Sasanian dynasty. One may also suppose that in certain figures of the Kayanid legendary circle reminiscences can be found of historical figures of Parthian and Sasanian (maybe even of Achaemenid) times and that Arsacids and Sasanians adapted older traditions to their own needs.

As Firdausī's Shāhnāmeh seems to indicate, the Kayanid part's lively interplay between king and nobility, with their manifold individualised personalities, seems to have been wanting in the Sasanid part of this tradition. King Wahrām Gōr, for example, bears certain features of the heroic character of the Kayanids, but he lacks the tragedy of a hero who serves an unjust master. Wahrām Chōbīn is an exception that confirms the rule - the dominance of the royal element. Without a doubt, Firdausī found that the Sasanid part's orientation towards the kings instead of the heroes of Iran is already in the Sasanian historical tradition. In contrast to the Kayanid part of the same tradition, the poet here obviously lacked the aristocratic-monarchical conflicts and antimonarchical discourses or the memory of great figures of the aristocracy of Sasanian times necessary to be able to create tragic constellations of acting characters. It may well be that the late Sasanian conflict between Khosrō II and Wahrām Chōbīn, who tried to legitimise his rebellion by referring to his Arsacid origin, was the reason why after Khosrō's victory a still existing, strong, aristocratic share in the Sasanid parts of the 'Book of Lords' or in other historical material had fallen victim to royal censorship as had the whole Arsacid part of the 'Iranian National History.'

\section{Conclusions}

Let us summarise briefly: the ruling kings of the house of Sāsān defined the criteria for a good lord themselves and made clear that they alone met these criteria - in contrast to their rivals for the throne, who were denied those qualities. This idea is transformed into a visual image in the triumphal relief at Naqsh-i Rustam. In the relief, Ardašīr - whose horse is trampling his rival Ardawān, the last Parthian king - re- 
ceives the ring of kingship from Ohrmazd, whose own horse is trampling his opponent, Ahreman. Ardašîr's grandson, Narseh, put this idea into words when he denied his grandnephew, Wahrām III, the ability to rule and introduced him and Wahnām, his nephew's counsellor, as the two evil usurpers very well known to an orally educated public. ${ }^{15}$ In the pre- and early Sasanian period, there must have been something like an alternative political public in aristocratic contexts, where criticism not of monarchy itself, but of monarchical autocracy and bad individual monarchs, was possible, and where people could speak of the co-operation of kings and aristocrats as being necessary for the well-being of Ėānšahr. Conversely, according to the Late Sasanian historical tradition, late antique Iran seems to have known royal ideological attempts to minimise the Parthian and the aristocratic share of the Iranian success story. Such a redefinition of the role of the king proved unsuccessful both ideologically and in terms of 'Realpolitik,' as was demonstrated in the Sasanian defeats against the armies of the Caliphs. However, the Sasanian model of kingship lived on, although it was revised, adapted to new needs and sometimes even replaced. It is our task to reconstruct and analyse the many ways of the model's impact on later generations of rulers, counsellors and authors.

15 M.R. Shayegan, Aspects of History and Epic in Ancient Iran: From Gaumāta to Wahnām, Cambridge, MA 2012; M.R. Shayegan, Persianism: Or Achaemenid Reminiscences in the Iranian and Iranicate World(s) of Antiquity, in: R. Strootman/M.J. Versluys (eds.), Persianism in Antiquity (Oriens et Occidens 25), Stuttgart 2017, 401-455, 451-453. 